\title{
Application of Equity Principles in the Development of E-Commerce Taxes
}

\author{
Dilli Trisna Noviasari ${ }^{1 *}$, Dyah Adriantini Sintha Dewi ${ }^{1}$, Habib Muhsin Syafingi ${ }^{1}$,
} Nurwati $^{1}$

\author{
${ }^{1}$ Department of Law, Universitas Muhammadiyah Magelang, Magelang, Indonesia \\ *Corresponding author.Email: dilli@ummgl.ac.id
}

\begin{abstract}
The most state revenue is from the tax sector. The government has tried its best to increase revenue from the tax sector from year to year. However, the development of tax variations by the government must not ignore the principle of equity. Likewise, in the imposition of e-commerce tax, the government is based on the principle of equity. To achieve these objectives this research uses an exploratory approach. With a qualitative explorative method this research produces explorative analytic data. Activities in analysing this include reducing the data obtained by looking at the concepts and development of the application of the principle of equity in the imposition of e-commerce tax and then presenting data that can provide definitions or explanations about the concepts or patterns studied in the study. The results of this study are the rejection of e-commerce actors against ministerial regulations that impose e-commerce tax because it is considered to have no principle of equity in the ministerial regulations. The existence of the principle of equity that is not considered in this ministerial regulation results in the e-commerce tax not working. Therefore, improvement of ministerial regulations governing the imposition of e-commerce tax must be made more holistic by applying the principle of equity in every joint of e-commerce tax provision.
\end{abstract}

Keywords: equity principles, e-commerce, taxes

\section{INTRODUCTION}

Tax is the most important part of financing a country's economic development. From the acquisition of state taxes, it can build the facilities and infrastructure needed by the community, the construction of various infrastructures and even the development of the moral character of the nation through training and education is inseparable from the need for funds. Current state management costs use the State Revenue and Expenditure Budget (APBN), whose main support comes from taxes. Taxes are the biggest contributor to state revenues, which account for almost $70 \%$ of total state revenue. Tax revenue can be in accordance with the target if the taxpayer is willing to meet the tax obligations imposed. One of the tax targets to be implemented is the imposition of e-commerce tax. E-commerce The phenomenon of e-commerce has transformed traditional business processes into digital-based businesses by eliminating market inefficiencies so as to form a business with a new, more sophisticated dimension. E-commerce changes the marketing process that was previously conventionally switched to a marketing model through a digital system where sellers and buyers do not deal directly. With the increase in e-commerce transactions, many parties are starting to realize the importance of comprehensive policies and information, so that the industry can grow and develop. This policy also deals with taxation policies for entrepreneurs through e-commerce. This taxation policy really needs equity content so that businesses with e- commerce can have a good scope of movement that leads to the advancement of e-commerce businesses and the progress of the country.

\section{METHOD}

This research uses exploratory method. Regulations regarding e-commerce, taxation, and aspects of equity in the view of the government and e-commerce businesses will be explored and linked to their usefulness in the taxation system for taxpayers and the government. After finding a balanced variable between e-commerce tax regulations and their usefulness, conclusions will be drawn on how to formulate appropriate regulations in building tax regulations for e-commerce businesses.

\section{RESULT AND DISCUSSION}

E-commerce business in Indonesia has entered a new stage. Technological progress in the field of e-commerce is not only growing very rapidly in Indonesia, but also the accompanying ecosystem will increase rapidly. The ecosystem that accompanies the core e-commerce business needs to be maintained, so that it can fully support the ecommerce business. Examples are freight forwarding services, money transfer services, trading application manufacturing services, and others [1]. Even in the industrial era 4.0, digital trading does not only involve goods in the form of immovable and inanimate objects, but 
can also trade in living and moving objects such as the sale of animals and other living objects in the form of ornamental plants, fruits and plants. drugs. By seeing the wide range of goods that can be transacted with digital media, this certainly has an impact on the extent of ecommerce activities in the industrial era 4.0, which are all fast digital and can penetrate space and time more efficiently. With the rise of e-commerce activities, government policies related to e-commerce need to be integrated in order to avoid overlapping or negating each other. For this reason, the Ministry of Finance needs to work closely with several other ministries to formulate ecommerce tax regulations which will take the form of a Minister of Finance Regulation (PMK). For example, purchasing goods from abroad through e-commerce. In this situation, the policy issued by the government not only regulates the validity of the transaction, but also the policy that regulates how the goods are treated when entering Indonesian customs territory until the goods are accepted by the buyer. With the increase in e-commerce transactions, many parties have begun to realize the importance of a comprehensive policy and information, so that this industry can grow and develop.

The e-commerce actors hope that the policies issued will not hamper the growth of the e-commerce industry in Indonesia. In the e-commerce tax policy, the government must ensure that taxes owed through conventional transactions and taxes owed through e-commerce transactions are levied according to applicable regulations. Thus, traders who sell conventionally or through ecommerce together have carried out their tax obligations. In addition, consumers who shop through conventional merchants or e-commerce are also subject to the same tax. In its development, the government can make arrangements related to the procedure for collecting taxes owed in the ecommerce industry. There is no difference in the tax rates imposed on transactions through e-commerce with transactions through conventional means. The government only regulates that traders who sell through e-commerce deposit a small portion of the tax owed from the transaction (Value Added Tax and Income Tax). Thus, the tax deposited can be calculated as a tax credit.

Various calculations for both Value Added Tax and Income Tax require the application of the right principle of equity that can represent the acceptance of e-commerce actors against the government policy that is implemented. The principle of equity becomes the most important principle leading to other principles in the form of the principle of legal certainty and expediency. Because if it is applied fairly, business people with e-commerce will feel more enthusiasm to follow government policies in the form of ecommerce taxation. With the principle of equity, it can foster a good legal response for e-commerce actors so that the legal benefit can automatically be achieved and the legal certainty will be increasingly strong.

The government has set rules related to e-commerce in several legal rules. Among them are listed in the 2014 Law on Trade which explains the legal certainty and understanding of Trade through Electronic Systems (PMSE) and consumers in conducting trading activities through the electronic system. In addition, there are Regulations on e-commerce taxation explained by the government through the Directorate General of Tax Circular Number SE/62/PJ/2013 concerning Affirmation of Taxation Provisions for e-commerce Transactions and Circular Letter SE-06/PJ/2015 concerning Withholding and or Income Tax Collection for e-commerce Transactions. The regulation consists of Income Tax $(\mathrm{PPh})$ and Value Added Tax (VAT) on e-commerce transactions which include taxes on business processes providing services for place and / or time (online market place), taxes on business processes of selling goods and/or services (classified ads), taxes on business processes of depositing sales proceeds to online market place merchants by online market place providers (daily deals) and taxes on online retail. Meanwhile the Ministry of Finance (MoF) withdrew Regulation of the Minister of Finance (PMK) Number 210/PMK.010/2018 concerning Tax Treatment of Trade Transactions through Electronic Systems (e-Commerce). The withdrawal of PMK as a result of the turmoil in the world of commerce with a digital system (e-commerce) in the form of the issue of lack of equity is applied in PMK Number 210 / PMK.010 / 2018. The PMK withdrawal was also carried out to coordinate and synchronize more comprehensively between Ministries/Institutions (K/L). Coordination is done to ensure that e-commerce arrangements are on target, fair, efficient and encourage the growth of the digital economic ecosystem by listening to input from all stakeholders [2].

Marketplace platform providers are those who provide facilities that function as electronic markets where platform users and service providers can offer goods and services to prospective buyers. Marketplace platform providers known in Indonesia include Blibli, Bukalapak, Elevenia, Lazada, Shopee, and Tokopedia. In addition to these companies, over-the-top actors in the transportation sector are also classified as marketplace platform providers. Businesses that carry out trading activities of goods and services through online retail, classified ads, daily deals, and social media must comply with the provisions related to VAT, $\mathrm{PPnBM}$, and $\mathrm{PPh}$ in accordance with applicable regulations [3].

With the existence of a more comprehensive arrangement by applying equity, it is hoped that the rules formed will be able to be implemented happily by the actors of ecommerce. Comprehensive regulations include what must be regulated and what about the taxation. Regarding ecommerce tax, the government certainly can implement it by referring to conventional trade tax, namely by imposing Value Added Tax (VAT), Sales Tax on Luxury Goods (PPnBM) and Income Tax (PPh). E-commerce tax policies should not be a barrier to business progress with ecommerce. In the tax policy formulation for traders with ecommerce must be made by taking into account that the taxes imposed are not double. This means VAT, PPnBM, and $\mathrm{PPh}$ must be seen whether the trader with e-commerce is a Taxable Entrepreneur (PKP) or not. Thus, the taxation on e-commerce must first be done with the data collection of entrepreneurs as PKP. After that, the method of trading is carried out whether conventionally in whole or in part, or even all trading activities carried out in a digital way, all or through e-commerce. After the data is generated, there will be a company identification that will have implications for 
tax policies that can be set for the businessman. Thus, double taxation can be avoided and equity can be applied. By knowing the data of entrepreneurs who trade in a purely conventional manner, or in a conventional and digital manner together or who purely trade in a digital manner, the principle of equity can be applied by providing a policy that every entrepreneur with a year's income at one level of income will be subject to VAT, PPnBM and PPh taxes according to the level of receipt. In addition, it can also be calculated by calculating the proportional tax rate. So, there is no difference between the imposition of VAT, PPnBM and $\mathrm{PPh}$ tax on business actors between e-commerce and conventional businesses. The difference is the level of annual revenue which will be calculated at a proportional tax rate. Therefore, the most important thing is to identify the trading business as PKP or not. Only then will be seen how to trade whether by digital, and conventional or by a mixture of both. After that the amount of monthly revenue is calculated. Then included in the calculation of proportional tax rates determined.

The use of e-commerce is important in implementing online strategies and promotions so as to expand market share. There are so many conveniences in the transaction process and updating information that is very supportive in the process of managerial decision making in e-commerce. Dissemination of information is faster with a wider level of dissemination. Decreasing operational costs and achieving company profitability and opportunities to increase company competitiveness [4]. Sales and marketing systems become more effective, dynamic and easy in increasing product expansion [5]. Internet-based trade drives globalization and networking in the business world. This condition makes the market and trade increasingly open without limits, large companies and equal opportunities for business people do not know whether they come from large, medium, or small companies that will make the economy of time actors who make the fastest who wins

The design of the E-Commerce system has the facility to store personal data with a username and password to anticipate misuse by irresponsible people. The ECommerce system provides payment facilities via bank transfer and Cash on Delivery. In addition, e-commerce applications provide interesting features and provide some rewards for e-commerce application visitors. This application technique can also be used to enter new data and change existing data and can provide information on data purchases made to shop owners. Provide information to the buyer regarding the delivery status of goods purchased and the status of payment via e-mail. In order for e-commerce implementation to work well, a hosting server that has a large capacity and fast access speed is needed. For further development, this E-Commerce system site can add news facilities regarding information and technology developments so that users and visitors can keep up with the latest developments. Also, in e-commerce is usually equipped with an electronic payment system using a credit card or other electronic payment systems such as PayPal. In e-commerce applications also provide several language options to make it easy for visitors who have foreign citizenship, and domiciled in Indonesia to make an order or transaction. With this sophisticated digital system, market effectiveness can work well. So that the impact of the world of commerce with the e-commerce system in Indonesia becomes the belle of choice to be occupied by many people engaged in the trade business both services and goods.

With the rise of trade with digital systems or e-commerce, it is necessary to have government policies that support trade with e-commerce to develop rapidly in Indonesia. So that it will have an impact on the progress of the Indonesian economy. Policies in the taxation sector that are good and that support e-commerce growth in Indonesia are highly needed by e-commerce actors. A tax system that applies the principle of equity is an inevitable choice for the government. With the right formulation in the economic growth of the country and society is an absolute requirement for the development of tax regulations for entrepreneurs with e-commerce systems. The reluctance to pay taxes can be avoided so that state revenues to finance development can go well and find dynamic additions to work.

\section{CONCLUSION}

Tax revenue is the main source of funding for national development, including development in the fields of education, health, and infrastructure that will increase the resilience and economic growth of Indonesia. A strong, stable, and just economy will in turn attract investment, create employment opportunities, and encourage prosperity. An inevitable turnaround is state expenditure and state revenue. From this cycle the state can run for the life of government administration and the interests of the people whose purpose is to create a prosperous state. One of the supporters of large state revenues is from the tax sector. Ecommerce tax is one of the taxes that had been imposed but has already been withdrawn. The problem is how to put the principle of equity in the e-commerce tax system. The existence of objections to e-commerce business actors on the grounds that the absence of the principle of equity in the e-commerce tax system that is put into effect makes the ecommerce tax payment jammed. Therefore, the formulation of an e-commerce tax system that establishes equity for ecommerce entrepreneurs is the first choice that must be made by the government. With the principle of equity embedded in the e-commerce tax system, it makes businesses no longer reluctant to pay e-commerce taxes. So that the e-commerce business actors with the government established a good relationship and mutually support the progress of the country's economy.

\section{ACKNOWLEDGMENT}

This research was conducted with independent funding. Thank you, the authors say to the Ministry of Finance of the Republic of Indonesia for sharing the data. In addition, many ecommerce businesses provide input on the tax policy model that can be implemented by the government. 
Kemenkeu.go.id/publikasi/berita/pmk-e-commerce-

\section{REFERENCES}

[1] Directorate General of Tax, Ministry of Finance of the Republic of Indonesia, "Kesetararaan Pajak untuk E-Commerce Mengatur Perpajakan pada Transaksi Digital, Media Keuangan, Vol. XIII No. 126, Maret 2018.

[2] Ministry of Finance of the Republic of Indonesia, "Kementerian Keuangan Tarik Peraturan Menteri Keuangan E-Commerce.

kemenkeu.go.id/publikasi/kemenkeu-tarik-pmk-ecommerce/html. Accessed October 11, 2019.

[3] Ministry of Finance of the Republic of Indonesia, "PMK E-Commerce Berlaku Mulai 1 April 2019. berlaku-mulai-1-april-2019/html. Accessed October 11, 2019.

[4] Julisar dan Miranda, E., "Pemakaian E-Commerce untuk Usaha Kecil dan Menengah Guna Meningkatkan Daya Saing', Comtech, Vol. 4. No.2, pp. 638-645, Desember 2013.

[5] Kosasi, S., "Pembuatan Sistem Informasi Penjualan Berbasis Web untuk Memperluas Pangsa Pasar Pasar. Seminar Nasional Teknologi Informasi dan Komunikasi (SENTIKA). Universitas Atma Jaya, Yogyakarta. ISSN: 9815. Pp.17-24, 2014. 